Research Article

www.ijrap.net

\title{
STUDY OF ANTIFUNGAL ACTIVITY OF HINGULIYA MANIKYARASA IN CANDIDA ALBICANS BY ITS VARIOUS CONCENTRATIONS
}

Inamdar Mahesh Prabhakar*, Patil Ragini Rajan, Mhaske Rajesh Harishchandra, Singh Satyendra Rajendra Prasad P.D.E.A's College of Ayurved and Research Center, Nigdi, Pradhikaran, Pune, Maharashtra, India

Received on: 07/05/13 Revised on: 21/06/13 Accepted on: 19/07/13

\author{
*Corresponding author \\ E-mail: drimp73@gmail.com \\ DOI: $10.7897 / 2277-4343.04424$ \\ Published by Moksha Publishing House. Website www.mokshaph.com \\ All rights reserved.
}

\section{ABSTRACT}

By the use of microbiological studies an Ayurvedic physician can choose accurate drug for particular disease. Keeping this view in mind present study was conducted to screen antifungal activity of Hinguliya manikya rasa on Candida albicans. For this, Hinguliya Manikyarasa was prepared by Kupipakwa rasayana method as given in Rasatarangini. The culture and sensitivity method used was tube dilution method (Agar slant method) so in the present study the drug was serially diluted from $0.5 \mathrm{mg} / \mathrm{ml}$ concentration to $8 \mathrm{mg} / \mathrm{ml}$ concentrations. All 90 samples were used and it was found that Candida albicans shows significant sensitivity to Hinguliya manikya rasa at $8 \mathrm{mg} / \mathrm{ml}$ concentration level as compare to Placebo.

Keywords: Candida albicans, Hinguliya Manikyarasa, Culture and sensitivity by Tube dilution (Agar slant Method).

\section{INTRODUCTION}

Diagnosis of the diseases can be done by Biochemistry, Microbiology and Pathology in medical science. They help the clinicians for the proper diagnosis of diseases because improper or late diagnosis and failure in the treatment leads to death. Acharya Charaka in Indian Medical Science has given three sutras or basic pillars as Hetu (Causes), Linga (Symptoms) and Aushadha (Medicine), in which Aushadha have unique importance ${ }^{1}$. In this modern era Aushadh i.e. Ayurvedic drugs are to be tested in the light of modern scientific techniques. Rasaushadhis are mainly prepared with the help of mineral or metallic compounds. These Rasaushadhis requires lesser dose, these are tasteless and having immediate action in body. Due to these properties Rasaushadhis are better than herbal drugs ${ }^{2}$. An arsenical compound comes under Rasaushadhi category. There are several Ayurvedic Rasaushadhis in practice to cure skin diseases since long time. But the need of the hour is to provide clear cut evidences to show the effectiveness of the Ayurvedic drug in a disease by laboratory findings. By employing microbiological analytical techniques for assessing the severity and type of the disease an Ayurvedic physician can easily choose the drug and try to evaluate its effectiveness specifically to the particular disease, by which specificity of the drug can be attained. A microbiologist can analyze the Indian medicinal plant based drug for its antifungal effects, on pathogens and at different dose levels. For example, if a skin diseased patient comes, the skin scrapping can be examined for the type of organism and proved antifungal Ayurvedic drugs for the particular organism can be prescribed to cure the patient quickly and effectively. Organic Arsenicals are useful in the treatment of protozoal infections caused by trypanosomes. Very little information is available about the usage of inorganic Arsenical Ayurvedic drugs as antimicrobial agents so it is important to study antimicrobial activity of Arsenicals compounds which are used in Ayurved. In 1990, Dr. U K Pillai did Ph.D. thesis on "Standard Preparation of Harital Bhasma and its clinical efficacy in certain skin diseases at I.P.G.T. and R.A. Gujarat Ayurveda University, Jamnagar and found that the Harital Bhasma produced significant growth inhibition of Staphylococcus aureus and Candida albicans while it did not produce any growth inhibition to Pseudomonas aeruginosa and Escherichia coli. As Harital is one of the ingredients of Hinguliya Manikyarasa and according to the above mentioned study Harital bhasma shows antifungal activity, this study was planned to assess the effect of Hinguliya Manikyarasa in serial dilution on the common fungus i.e. Candida albicans.

\section{Aim}

Observe the antimicrobial activity of Hinguliya Manikyarasa against Candida albicans by culture and sensitivity method.

\section{Objectives}

Identify the organism by its morphological and cultural characteristics. To observe the sensitivity or resistance of Hinguliya Manikyarasa, in vitro.

\section{Hypothesis}

Does Candida albicans are sensitive to Hinguliya Manikyarasa?

\section{MATERIALS AND METHODS \\ Materials}

Literature review was done from classical Ayurvedic texts, Modern literature and Web references regarding Hinguliya Manikyarasa and culture sensitivity of microorganisms (i.e. fungus).

\section{Test fungus}

Candida albicans - The cultures of the fungus were obtained from the Department of Microbiology M.P. Shah Medical College, Jamnagar, India. 


\section{Methods}

Organisms were grown on artificial media in laboratory and then isolated. The fungus Candida albicans was isolated. The tubes containing the fungus were exposed to Hinguliya Manikyarasa and these tubes were kept in incubator at $37^{\circ} \mathrm{C}$ for 24 hours. Then the results were observed. This study includes collection of appropriate sample, fungal culture, isolation and identification, preparation of Hinguliya Manikyarasa and sensitivity or resistance of fungus to Hinguliya Manikyarasa.

\section{Collection of specimen}

The Collections of appropriate specimen was taken into a sterilized container and was sent for culture and sensitivity to the laboratory. 15 samples were used for each dilution as well as for placebo i.e. total 90 samples.

\section{Fungal culture, isolation and identification}

Fungus from specimen was grown on an artificial medium in laboratory. Isolation and identification was made after growth of fungus, by cultural, morphological and biochemical characteristics.

\section{Material for fungal culture}

Sabouraud's agar, Petri dish, Nichrome wire loop, Spirit lamp, Incubator, Hot air oven, Normal saline, Slides, Autoclaved test tubes, Gram stain kit, appropriate specimen, Inoculation chamber, Gloves, Microscope and Sterile container.

\section{Procedure for fungal culture and sensitivity}

The antimicrobial parameters were determined by serial dilution with agar slant method ${ }^{3}$.

\section{Dilution tests}

Employ medicine in serially diluted concentrations in solid agar or broth media containing a culture of the test microorganism. The Minimal Inhibitory Concentration (MIC) was determined by the agar slant method. The lowest concentration of the tubes which did not show any visible growth after 18-24hours of incubation in macroscopic evaluation was considered as the MIC. Many anaerobes can only be tested by a dilution method and this is also true for many fungi. The dilutions can be made in broth or in agar ${ }^{4}$.

\section{Observation of colony character}

Candida albicans differ in their shapes, size, elevation, margin, surface texture, color and consistency.

\section{Test micro-organisms (Candida albicans)}

Candida albicans is yeast like fungus. It is an ovoid or spherical budding cell, which produces pseudomycelia both in cultures and in tissues. Candida species are normal inhabitants of the skin and mucosa. Cultures can be obtained readily on Sabouraud's and on ordinary bacteriological culture media ${ }^{5}$.

\section{Isolating characteristics}

Colonies are creamy white, smooth and are with a yeasty odor.

\section{Pathogenecity}

Candida albicans causes infections of skin, mucosa and rarely of internal organs known as Candidiasis ${ }^{6}$.

\section{Test Drug \\ Ingredients of Hinguliya Manikyarasa \\ - Purified Hingula (Cinnabar) - 90g \\ - Purified Gandhak (Sulphur) - $\quad$-90g \\ - Purified Harital (Yellow Orpiment) - 90g \\ - Juice of Flower of Palash (Butea frondosa) - Q.S.}

Hinguliya Manikyarasa prepared by textual method as given in Rasa Tarangini by Kupi-pakwa Rasayan method before that Hingul, Harital and Gandhaka were purified as per the references given in the texts and the purified minerals were triturated with the juice of flowers of Butea frondos $a^{7-8}$. The drug prepared by this method was used in the form of suspension in 3\% Tween 80 solution.

\section{Media}

Subourauds agar (Himedia India Limited)

Antifungal activities of drug were screened by serial tube dilution method as described by Cruickshank and Coworkers (1975). This method consisted of incorporating Hinguliya Manikyarasa in various concentrations in growth media suitable to the test organism and monitoring the growth. Initially pilot study was carried out on 7 samples of Candida albicans by using $0.5 \mathrm{mg} / \mathrm{ml}$ concentrated and $8 \mathrm{mg} / \mathrm{ml}$ solutions of Hinguliya Manikyarasa.

\section{Composition of medium - Sabouraud's Agar}

- Dextrose - $20 \mathrm{~g}$

- Peptone - 5g

- Agar - 10g

- Distilled Water - 500ml

All the three ingredients dissolved in $500 \mathrm{ml}$ of distilled water and $\mathrm{pH}$ was adjusted to 7.6

\section{Procedure}

The Sabouraud's medium was reconstituted and $\mathrm{pH}$ was adjusted to the required level and sterilized by autoclaving for 1hour under 20pound pressures per square inch. Simultaneously a series of drug concentration were prepared by serial dilution. Initially in one test tube drug solution of $16 \mathrm{mg} / \mathrm{ml}$ was prepared. $1 \mathrm{ml}$ drug solution was taken from above test tube in which $1 \mathrm{ml}$ distilled water was added to it, thus drug solution of $8 \mathrm{mg} / \mathrm{ml}$ was prepared. Again $1 \mathrm{ml}$ drug solution from this test tube was taken and by adding $1 \mathrm{ml}$ distilled water a drug solution of $4 \mathrm{mg} / \mathrm{ml}$ was prepared. By the same process drug solution of $2 \mathrm{mg} / \mathrm{ml}, 1 \mathrm{mg} / \mathrm{ml}$ and $0.5 \mathrm{mg} / \mathrm{ml}$ concentration were prepared. For each time 6 autoclaved test tubes were used in which one was for control and 5 were for test drug solutions. 5 test tubes were taken and $9.5 \mathrm{ml}$ Sabouraud's agar was added in each test tube and $0.2 \mathrm{ml}$ drug solution of each concentration was added in each test tube except control in which $0.2 \mathrm{ml}$ of $3 \%$ Tween 80 was added and mixed well. Again the test tubes were autoclaved. After autoclaving Sabouraud's medium (with drug solution) slant were prepared and kept for incubation for 24hours to rule out contamination. The cultured organisms were 
taken and inoculated over slants. The slants were incubated and fungus observation was made after 8days. The same procedure was carried out for 15 samples of each dilution.

\section{RESULTS AND DISCUSSION}

Initially a pilot study was carried out in which $0.5 \mathrm{mg} / \mathrm{ml}$ and $8 \mathrm{mg} / \mathrm{ml}$ drug concentrations of Hinguliya Manikyarasa were selected. In each group 7 samples along with Placebo group were observed. The results showed that growth inhibitions were not observed i.e. complete turbidity was seen in all the 7 samples of $0.5 \mathrm{mg} / \mathrm{ml}$ concentration and Placebo group which indicates that the Candida albicans was not sensitive at this drug concentration level. The growth inhibition was seen. It means that the tubes were completely clear in all the 7 samples of $8 \mathrm{mg} / \mathrm{ml}$ concentration indicating that the
Candida albicans was sensitive at this drug concentration level. So the study was conducted by using serial dilution from $0.5 \mathrm{mg} / \mathrm{ml}$ to $8 \mathrm{mg} / \mathrm{ml}$ concentrations (Table 1 ). The drug Hinguliya Manikyarasa was serially diluted and concentrations were maintained as $0.5,1,2,4$ and $8 \mathrm{mg} / \mathrm{ml}$. In case of $0.5 \mathrm{mg} / \mathrm{ml}$ and $1 \mathrm{mg} / \mathrm{ml}$ drug concentrations of Hinguliya Manikyarasa, the results shown that growth inhibitions were not detected i.e. turbidity was seen in all the 30 samples which mean that the Candida albicans was resistant at these drug concentration levels (Table 2). In case of $2 \mathrm{mg} / \mathrm{ml}$ and $4 \mathrm{mg} / \mathrm{ml}$ drug concentrations of Hinguliya Manikyarasa, the results showed that partial growth inhibitions i.e. intermediate turbidity were seen in all the 30 samples indicating that Candida albicans were partially sensitive at these drug concentration levels (Table 3).

Table 1: Table showing Effect of $0.5 \mathrm{mg} / \mathrm{ml}$ and $8 \mathrm{mg} / \mathrm{ml}$ concentrations of Hinguliya Manikyarasa and Placebo on Candida albicans during Pilot study

\begin{tabular}{|c|c|c|c|}
\hline Concentration & Turbidity & Intermediate Turbidity & Clear \\
\hline Placebo & 07 & 00 & 00 \\
\hline $0.5 \mathrm{mg} / \mathrm{ml}$ & 07 & 00 & 00 \\
\hline $8 \mathrm{mg} / \mathrm{ml}$ & 00 & 00 & 07 \\
\hline
\end{tabular}

Growth inhibitions were not observed in all the 7 samples of $0.5 \mathrm{mg} / \mathrm{ml}$ concentration and there was growth inhibition seen in all the 7 samples of $8 \mathrm{mg} / \mathrm{ml}$ concentration. So the study was conducted by using serial dilution from $0.5 \mathrm{mg} / \mathrm{ml}$ to $8 \mathrm{mg} / \mathrm{ml} \mathrm{concentrations}$.

Table 2: Table showing Effect of $0.5 \mathrm{mg} / \mathrm{ml}$ and $1 \mathrm{mg} / \mathrm{ml}$ concentrations of Hinguliya Manikyarasa and Placebo on Candida albicans

\begin{tabular}{|c|c|c|c|}
\hline Concentration of Hinguliya Manikyarasa & Turbidity & Intermediate Turbidity & Clear \\
\hline $0.5 \mathrm{mg} / \mathrm{ml}$ & 15 & 00 & 00 \\
\hline $1 \mathrm{mg} / \mathrm{ml}$ & 15 & 00 & 00 \\
\hline Placebo & 15 & 00 & 00 \\
\hline
\end{tabular}

Growth inhibitions were not observed in all the 15 samples of $0.5 \mathrm{mg} / \mathrm{ml}$ and $1 \mathrm{mg} / \mathrm{ml}$ concentrations and in Placebo group as well.

Table 3: Table showing Effect of $2 \mathrm{mg} / \mathrm{ml}$ and $4 \mathrm{mg} / \mathrm{ml}$ concentrations of Hinguliya Manikyarasa and Placebo on Candida albicans

\begin{tabular}{|c|c|c|c|}
\hline Concentration of Hinguliya Manikyarasa & Turbidity & Intermediate Turbidity & Clear \\
\hline $2 \mathrm{mg} / \mathrm{ml}$ & 00 & 15 & 00 \\
\hline $4 \mathrm{mg} / \mathrm{ml}$ & 00 & 15 & 00 \\
\hline Placebo & 15 & 00 & 00 \\
\hline
\end{tabular}

The intermediate turbidity was observed in all the 15 samples of $2 \mathrm{mg} / \mathrm{ml}$ and $4 \mathrm{mg} / \mathrm{ml}$ concentrations and complete turbidity was observed in Placebo group.

Table 4: Table showing Effect of $8 \mathrm{mg} / \mathrm{ml}$ concentration of Hinguliya Manikyarasa and Placebo on Candida albicans

\begin{tabular}{|c|c|c|c|}
\hline Concentration of Hinguliya Manikyarasa & Turbidity & Intermediate Turbidity & Clear \\
\hline $8 \mathrm{mg} / \mathrm{ml}$ & 00 & 00 & 15 \\
\hline Placebo & 15 & 00 & 00 \\
\hline
\end{tabular}

The tubes were observed completely clear in all the 15 samples of $8 \mathrm{mg} / \mathrm{ml}$ concentration and complete turbidity was observed in Placebo group.

Table 5: Table showing effect of all concentrations of Hinguliya Manikyarasa and Placebo on Candida albicans

\begin{tabular}{|c|c|c|c|}
\hline Concentration of Hinguliya Manikyarasa & Turbidity & Intermediate Turbidity & Clear \\
\hline Placebo & 15 & 00 & 00 \\
\hline $0.5 \mathrm{mg} / \mathrm{ml}$ & 15 & 00 & 00 \\
\hline $1 \mathrm{mg} / \mathrm{ml}$ & 15 & 00 & 00 \\
\hline $2 \mathrm{mg} / \mathrm{ml}$ & 00 & 15 & 00 \\
\hline $4 \mathrm{mg} / \mathrm{ml}$ & 00 & 15 & 00 \\
\hline $8 \mathrm{mg} / \mathrm{ml}$ & 00 & 00 & 15 \\
\hline
\end{tabular}

Table 6: Table showing statistical analysis of Hinguliya Manikyarasa and Placebo on Candida albicans

\begin{tabular}{|c|c|}
\hline Concentration of Hinguliya Manikyarasa & Significant / Not Significant \\
\hline $0.5 \mathrm{mg} / \mathrm{ml}$ & Not Significant \\
\hline $1 \mathrm{mg} / \mathrm{ml}$ & Not Significant \\
\hline $2 \mathrm{mg} / \mathrm{ml}$ & Significant \\
\hline $4 \mathrm{mg} / \mathrm{ml}$ & Significant \\
\hline $8 \mathrm{mg} / \mathrm{ml}$ & Highly Significant \\
\hline Placebo & Not Significant \\
\hline
\end{tabular}




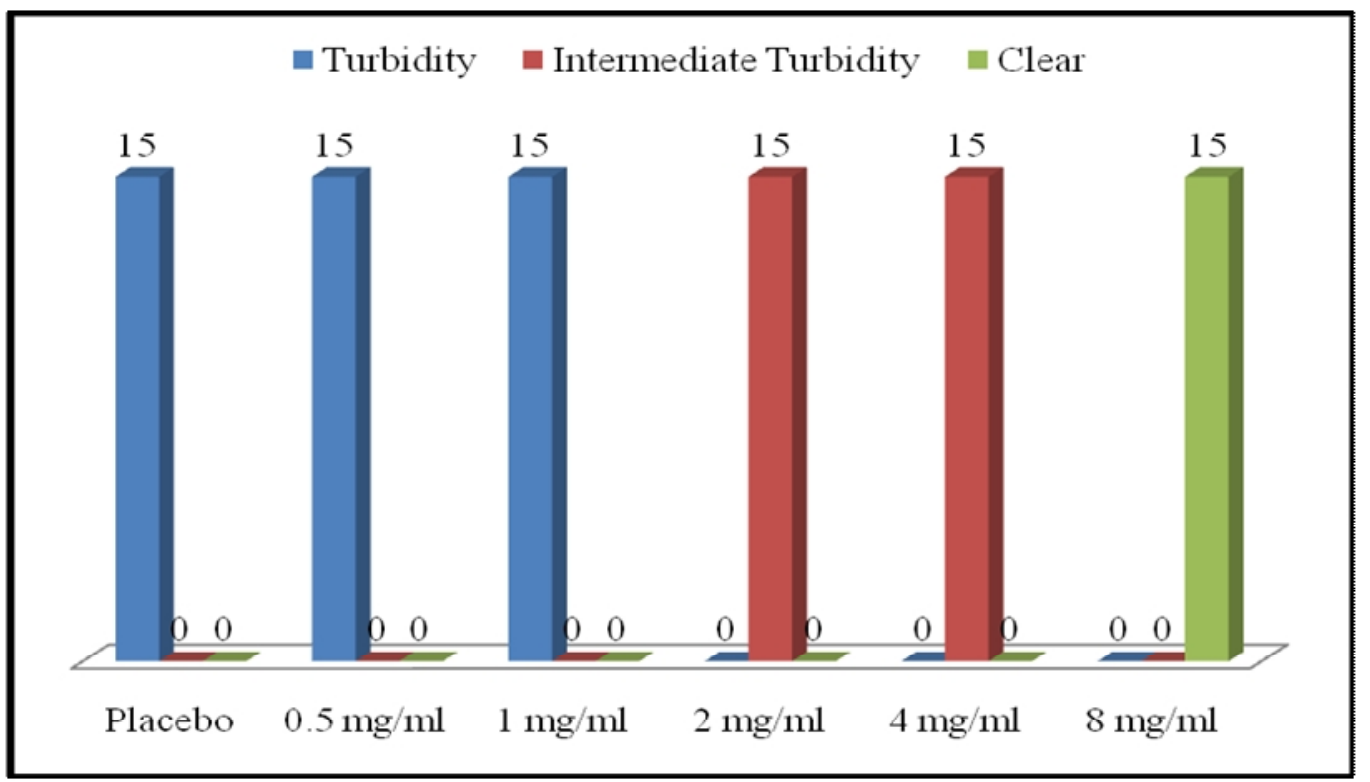

Figure 1: Effect of all concentrations of Hinguliya Manikyarasa and Placebo on Candida albicans

When the study was carried out at $8 \mathrm{mg} / \mathrm{ml}$ drug concentrations of Hinguliya Manikyarasa, the results were observed that complete growth inhibitions i.e. the samples tubes were seen clear indicating that Candida albicans were sensitive at this $8 \mathrm{mg} / \mathrm{ml}$ drug concentration level. As this was the lowest concentration level where complete growth inhibition was observed which should be considering as minimum inhibition concentration (MIC) (Table 4). In all the Placebo group and samples having $0.5 \mathrm{mg} / \mathrm{ml}, \quad 1.0 \mathrm{mg} / \mathrm{ml}$ concentrations turbidity was observed in all 15 samples whereas the samples having $2.0 \mathrm{mg} / \mathrm{ml}, 4 \mathrm{mg} / \mathrm{ml}$ concentrations showed intermediate turbidity (i.e. significant) and the sample having $8 \mathrm{mg} / \mathrm{ml}$ concentration showed clarity (i.e. Highly significant) (Table 5-6 and Graph 1).

\section{CONCLUSION}

In the present study of antifungal activity of various concentrations of Hinguliya Manikyarasa, the drug did not show antifungal activity at $0.5 \mathrm{mg} / \mathrm{ml}$ and $1 \mathrm{mg} / \mathrm{ml}$ concentration, but the test drug had shown partial antifungal activity at $2 \mathrm{mg} / \mathrm{ml}$ and $4 \mathrm{mg} / \mathrm{ml}$ concentrations whereas complete antifungal activity was observed at $8 \mathrm{mg} / \mathrm{ml}$ drug concentration (highly significant) for Candida albicans.

\section{ACKNOWLEDGEMENT}

pay my sincere thanks to my Co-Authors, Dr. Ragini R. Patil, Principal, H.O.D. Rognidan Dept., Dr. Rajesh R. Mhaske, Reader Rognidan Dept., Dr. Satyendrakumar Singh and Lecturer Rognidan Dept. for their valuable help and contribution in this work. I am overwhelming thankful to Dr. U. K. Pillai whose clinical work on effect of Harital bhasma against common bacteria and fungi inspired me to do this Research work. I am also obliged to Dr. Damodar Pandey, H.O.D, Rasashastra
Dept. and Dr. B. Ravishankar, Professor and H.O.D. Pharmacology department IPGT and RA Gujarat Ayurved University, Jamnagar, India for their encouragement and support regarding the study.

\section{REFERENCES}

1. Brahmanand Dr Tripathi. Charakasamhita, Charaka Chandrika Hindi Commentary, Chaukhambha Surabharati Prakashan, Varanasi, Revised edition 2001, Sutrasthan, Adhyay 1, Shloka No.24 p. 9

2. Shastri Kaviraj Shri Ambikadatta. Rasaratnasamuchchaya, Suratnojjvala Hindi commentary and notes, Chaukhambha Amarabharati Prakashan, Varanasi, IX ed; 1995. p. 570

3. Ananthanarayana and Panikars, Textbook of Microbiology, Universities Press, India Private Limited, Hyderabad, $8^{\text {th }}$ ed, Chapter 66- Laboratory Control of Antimicrobial Therapy, p. 619; Chapter 65- Medical Mycology; p. 607

4. Web Ref - (12 January 2013) www.google.com

5. Godkar Dr Prafulla B. Textbook of Medical Laboratory Technology, Bhalani publishing house Mumbai, II ${ }^{\text {nd }}$ ed, chapter 3Clinical Mycology- Study of Candida albicans; 2008. p. 596

6. Harrisons Principles of Internal Medicine, Mcgraw- Hill companies, Health professions division, printed in USA, $14^{\text {th }} \mathrm{ed}$, Volume- I, Section 15- Fungal infections, chapter 207-Candidiasis; 1998. p. 1154

7. Sharma Vd Sadanand. Rasatarangini, Motilal Banarasidas Prakashan Delhi, VII ed, Tarang 9, shloka no.54-55 p. 208, shloka no. 12 , p. 201, Tarang 11, shloka no. 19,20 p. 247

8. Madhav Acharya Shri. Ayurved Prakash, edited with the Arthavidyotini and Arthaprakashini Sanskrit and Hindi commentaries by Shri Vaidya Vachaspati. Gularaj Mishra, Chaukhambha Bharati Prakashan, Varanasi, IV ed, Adhyaya 2 shloka 21-24; 1994. p. 261

\section{Cite this article as:}

Inamdar Mahesh Prabhakar, Patil Ragini Rajan, Mhaske Rajesh Harishchandra, Singh Satyendra Rajendra Prasad. Study of antifungal activity of Hinguliya manikyarasa in Candida albicans by its various concentrations. Int. J. Res. Ayurveda Pharm. 2013;4(4):570-573 http:// dx.doi.org/10.7897/2277-4343.04424 